\title{
ANALISIS RASIO LIKUIDITAS, SOLVABILITAS, DAN PROFITABILITAS DALAM MENDUKUNG PEMBIAYAAN PADA PT BANK DANAMON INDONESIA, TBK.
}

\author{
Lia Dahlia Iryani ${ }^{*}$ dan Herlina ${ }^{* *}$
}

\begin{abstract}
ABSTRAK
Penilaian kinerja pada aspek keuangan perusahaan lebih sering menggunakan teknik analisis rasio keuangan. Analisis ini membutuhkan laporan keuangan sedikitnya dua tahun terakhir. Dengan analisis rasio keuangan akan dapat diketahui tingkat likuiditas, solvabilitas, dan profitabilitas perusahaan. Teknik penelitian yang digunakan adalah analisis kuantitatif (nonstatistik). Dari hasil penelitian dapat diperoleh hasil bahwa rasio likuiditas, solvabilitas, dan profitabilitas cenderung mengalami peningkatan dan pembiayaan PT Bank Danamon Indonesia, Tbk. dalam keadaan sehat, berdasarkan hasil pengujian yang dilakukan bahwa pembiayaan pada PT Bank Danamon Indonesia, Tbk. pada tahun 2011 mengalami kenaikan sebesar 777.962. Hal ini disebabkan adanya kenaikan pada tingkat solvabilitas. Peningkatan pembiayaan terjadi disebabkan kondisi PT Bank Danamon Indonesia, Tbk. dalam keadaan liquid jika dilihat dari tingkat likuiditas.
\end{abstract}

Kata Kunci: Rasio Likuiditas, Rasio Solvabilitas, Rasio Profitabilitas, dan Pembiayaan

\section{ABSTRACT}

The performance assessment of the financial aspects of the company more frequently using financial ratio analysis techniques. This analysis requires the financial statements at least the last two years. With the financial ratio analysis will be able to determine the level of liquidity, solvency, and profitability. A research technique that used is quantitative analysis (nonstatistik). From the research result showed that the ratio of liquidity, solvency, and profitability tends to increase and financing of PT Bank Danamon Indonesia, Tbk was in a healthy state, based on the results of tests performed that financing in PT Bank Danamon Indonesia, Tbk in 2011 increased by 777 962. This is due to an increase in the level of solvency. Increased financing occurs due to the condition of PT Bank Danamon Indonesia, Tbk. in a liquid state when viewed from the level of liquidity.

Keywords: Liquidity Ratios, Solvency Ratios, Profitability Ratios, and Financing

\footnotetext{
${ }^{*}$ Dosen Tetap Fakultas Ekonomi Universitas Pakuan

${ }^{* *}$ Mahasiswa Fakultas Ekonomi Universitas Pakuan
} 


\section{PENDAHULUAN}

Perkembangan di dunia perbankan yang sangat pesat serta tingkat kompleksitas yang tinggi dapat berpengaruh terhadap performa suatu bank. Ada banyak yang menyebabkan penurunan performa bank, seperti lemahnya kondisi internal bank yang meliputi manajemen yang kurang memadai, pemberian kredit kepada kelompok atau grup usaha sendiri, serta modal yang tidak dapat mengkover terhadap resiko-resiko yang dihadapi oleh bank tersebut. Dengan adanya penurunan kinerja bank dapat menurunkan pula kepercayaan masyarakat.

Penurunan kinerja bank dapat menurunkan pula kepercayaan masyarakat. Pengertian bank dalam PSAK 31 salah satunya yaitu bank merupakan industri yang dalam kegiatan usahanya mengandalkan kepercayaan masyarakat sehingga tingkat kesehatan bank perlu dipelihara. Pemeliharaan kesehatan bank antara lain dilakukan dengan tetap menjaga likuiditasnya sehingga bank dapat memenuhi kewajiban kepada semua pihak yang menarik atau mencairkan simpanannya sewaktu-waktu. Kesiapan memenuhi kewajiban setiap saat ini menjadi sangat penting artinya mengingat peranan bank sebagai lembaga yang berfungsi memperlancar lalu lintas pembayaran. Di samping faktor likuiditas, keberhasilan usaha bank juga ditentukan oleh kesanggupan para pengelola dalam menjaga rahasia keuangan nasabah yang dipercayakan kepadanya serta keamanan atas uang atau aset lainnya yang dititipkan pada bank.

Pentingnya menjaga kepercayaan masyarakat terhadap bank karena kegiatan utama bank adalah penghimpunan dana dari masyarakat kemudian menyalurkannya dengan tujuan untuk memperoleh pendapatan.
Dari hal tersebut maka setiap bank perlu menjaga kondisi kesehatannya. Dengan memiliki kinerja yang baik, masyarakat pemodal akan menanamkan dananya pada saham bank tersebut. Hal ini menunjukkan adanya kepercayaan masyarakat bahwa bank tersebut dapat memenuhi harapannya.

Kondisi kesehatan atau kinerja bank dapat kita analisis melalui laporan keuangan. Informasi yang terdapat dalam laporan keuangan akan membantu berbagai pihak dalam merumuskan atau pertimbangan dalam mengambil keputusan dalam hal keuangan. Dengan menggunakan laporan keuangan yang diperbandingkan termasuk data-data tentang perubahan-perubahan yang terjadi dalam jumlah rupiah dan persentase maka beberapa rasio keuangan akan membantu dalam menganalisa dan menginterpretasikan posisi keuangan suatu perusahaan.

Dengan mengadakan analisa terhadap pos-pos neraca akan dapat diketahui atau diperoleh gambaran tentang posisi keuangannya. Sedangkan analisa terhadap laporan laba rugi akan memberikan gambaran tentang hasil atau perkembangan usaha perusahaan yang bersangkutan. Dengan menggunakan laporan yang diperbandingkan, termasuk data tentang perubahan-perubahan yang terjadi dalam jumlah rupiah, prosentase serta trennya, rasio keuangan suatu perusahaan dalam menentukan langkahlangkah yang akan diambil guna keberlangsungan perusahaan itu sendiri.

Adapun tujuan penelitian ini adalah 1) Untuk mengetahui perhitungan rasio likuiditas, solvabilitas, dan profitabilitas yang dilakukan PT Bank Danamon Indonesia, Tbk.; 2) Untuk mengetahui kebijakan perusahaan mengenai pembiayaan yang ada dan prosedur yang diterapkan pada PT Bank Danamon Indonesia, Tbk.; dan 3) Untuk mengetahui pengaruh rasio likuiditas, 
solvabilitas, dan profitabilitas dalam mendukung pembiayaan pada PT Bank Danamon Indonesia, Tbk.

\section{LANDASAN TEORI}

\subsection{Analisis Laporan Keuangan}

Menurut Harahap (2008) mengemukakan analisis laporan keuangan sebagai pengurai pos-pos laporan keuangan menjadi unit informasi yang lebih kecil dan melihat hubungannya yang bersifat signifikan atau mempunyai makna antara satu dengan yang lain baik data kuantitatif maupun nonkuantitatif dengan tujuan untuk mengetahui kondisi keuangan lebih dalam yang sangat penting dalam proses menghasilkan keputusan yang tepat. Adapun tujuan laporan keuangan memberikan informasi yang:

1. Bermanfaat dalam pembuatan keputusan pembiayaan dan investasi oleh pihak yang ingin memahami kegiatan ekonomi dan bisnis perusahaan.

2. Membantu kreditor dan investor yang ada atau potensial, serta pemakai lain dalam menentukan jumlah, waktu, dan ketidakpastian aliran kas di masa mendatang.

3. Mengenai sumber-sumber ekonomi, tuntutan terhadap sumber ekonomi, dan perubahan di dalamnya.

Dalam menganalisa dan menilai posisi keuangan dan potensi perusahaan, faktor-faktor utama yang harus mendapat perhatian oleh penganalisa menurut Munawir (2007, 31-34) adalah:

1. Likuiditas: menunjukkan kemampuan suatu perusahaan untuk memenuhi kewajiban keuangannya yang harus segera dipenuhi atau kemampuan perusahaan untuk memenuhi kewajiban keuangan pada saat ditagih. Perusahaan yang mampu memenuhi kewajiban keuangannya tepat pada waktunya berarti perusahaan tersebut dalam keadaan likuid. Selain itu, apabila perusahaan mempunyai aset lancar yang lebih besar daripada hutang lancarnya.

2. Solvabilitas: menunjukkan kemampuan perusahaan untuk memenuhi kewajiban keuangannya apabila perusahaan tersebut dilikuidasi baik kewajiban keuangan jangka pendek maupun jangka panjang. Suatu perusahaan dikatakan solvable apabila perusahaan tersebut mempunyai aset yang cukup untuk membayar semua hutangnya.

Dalam hubungannya antara likuiditas dan solvabilitas ada empat kemungkinan keadaan yang dapat dialami oleh perusahaan (Fahmi 2011, 174)

a. Perusahaan yang likuid dan solvable

Likuid dan solvable merupakan kondisi di mana suatu perusahaan dinyatakan sehat dan dalam keadaan baik karena mampu melunasi kewajiban-kewajiban yang bersifat jangka pendek dan mampu melunasi hutanghutang yang jatuh tempo secara tepat waktu. Pada posisi ini saham perusahaan dilihat dalam kondisi yang baik atau konstan bertumbuh, artinya secara finansial dan non finansial perusahaan dianggap tidak memiliki kendala atau permasalahan apa pun.

b. Perusahaan yang likuid dan insovable

Likuid dan insovable merupakan kondisi di mana suatu perusahaan tidak lagi 
memiliki keseimbangan finansial secara baik karena likuiditasnya dianggap sehat namun solvabilitasnya dianggap berada dalam posisi bermasalah bahkan cenderung tidak lagi tepat waktu (insovable). Pada posisi ini perusahaan sudah mengalami kondisi financial distress, di mana mungkin saja dana untuk membayar utang yang sudah jatuh tempo tersebut dipakai untuk membayar kewajiban jangka pendeknya.

c. Perusahaan yang ilikuid dan insovable

Di titik ini kondisi perusahaan berada dala kondisi menuju kebangkrutan. Kondisi bangkrut terjadi pada saat sebuah perusahaan tidak mampu lagi melunasi kewajiban jangja pendek dan utang-utang yang ada diberbagai tempat yang jatuh tempo. Jika tidak cepat diatasi maka perusahaan ini kemungkinan akan mengalami kondisi untuk diakuisisi oleh perusahaan lain atau melakukan kebijakan merger.

d. Perusahaan yang ilikuid dan solvable

Kondisi di mana perusahaan tidak lagi memiliki keseimbangan finansial secara baik. Hal ini terjadi karena likuiditasnya sudah tidak sehat lagi atau pihak manajemen perusahaan sudah tidak mampu lagi memenuhi kewajiban finansialnya secara tepat waktu. Namun di sisi lain, kemampuan perusahaan untuk membayar utang-utang yang jatuh tempo masih sangat baik. Ketidakseimbangan ini mungkin saja terjadi karena dana jangka pendeknya dari likuiditas dipakai untuk membayar utang yang telah jatuh tempo, salah satu analisa pihak manajemen adalah memindahkan sementara dana likuiditas daripada nama baik perusahaan diperbankan turun atau bahkan lebih jauh memungkinkan agunan perusahaan diambil oleh bank karena faktor tidak lagi mampu membayar utangutang tersebut.

3. Profitabilitas: menunjukkan kemampuan perusahaan untuk menghasilkan laba selama periode tertentu. Profitabilitas suatu perusahaan diukur dengan kesuksesan dan kemampuan perusahaan menggunakan asetnya secara produktif. Dengan demikian profitabilitas suatu perusahaan dapat diketahui dengan membandingkan antara laba yang diperoleh dalam suatu periode dengan jumlah aset atau jumlah modal perusahaan tersebut.

4. Stabilitas usaha: menunjukkan kemampuan perusahaan untuk melakukan usahanya dengan stabil yang diukur dengan mempertimbangkan kemampuan perusahaan untuk membayar beban bunga atas hutang-hutangnya tersebut tepat pada waktunya serta kemampuan perusahaan untuk membayar dividen secara teratur 
kepada para pemegang saham tanpa mengalami hambatan atau krisis keuangan.

\section{a. Pembiayaan}

Menurut Antonio (2001, 160) menjelaskan bahwa pembiayaan merupakan salah satu tugas pokok bank, yaitu pemberian fasilitas dana untuk memenuhi kebetuhan pihak-pihak yang merupakan defisit unit. Menurut UU No. 10 tahun 1998 tentang Perbankan (1998, 3) menyatakan bahwa pembiayaan adalah penyediaan uang atau tagihan yang dipersamakan dengan itu berdasarkan persetujuan atau kesepakatan antara bank dengan pihak lain yang mewajibkan pihak yang dibiayai untuk mengembalikan uang atau tagihan tersebut setelah jangka waktu tertentu dengan imbalan atau bagi hasil. Tujuan pembiayaan adalah untuk meningkatkan kesepakatan kerja dan kesejahteraan ekonomi.

Dalam melakukan penilaian permohonan pembiayaan, bagian merketing harus memperhatikan beberapa prinsip utama yang berkaitan dengan kondisi calon nasabah, antara lain:

1. Character: penilaian terhadap karakter atau kepribadian calon penerima pembiayaan dengan tujuan untuk memperkirakan kemungkinan bahwa penerima pembiayaan dapat memenuhi kewajibannya.

2. Capacity: penilaian secara subjektif tentang kemampuan penerima pembiayaan untuk melakukan pembayaran.

3. Capital: penilaian terhadap kemampuan modal yang dimiliki oleh calon penerima pembiayaan yang diukur dengan posisi perusahaan secara keseluruhan yang ditunjukkan oleh rasio finansial dan penekanan pada komposisi modalnya.

4. Collateral: jaminan yang dimiliki oleh calon penerima pembiayaan.

5. Condition: lembaga keuangan harus melihat kondisi ekonomi yang terjadi di dalam masyarakat secara spesifik melihat adanya keterkaitan dengan jenis usaha yang dilakukan oleh calon penerima pembiayaan.

\section{METODE ANALISIS}

Penelitian ini menggunakan teknik pengolahan dan analisis data secara kuantitatif terhadap data historis laporan keuangan perusahaan. Data yang diperoleh dari perusahaan diidentifikasi dan dianalisis menggunakan analisis rasio keuangan.

IV. HASIL DAN PEMBAHASAN

4.1. Rasio Likuiditas, Solvabilitas, dan Profitabilitas pada PT Bank Danamon Indonesia, Tbk.

\subsubsection{Rasio Likuiditas pada PT Bank} Danamon Indonesia, Tbk

Rasio likuiditas mengukur kemampuan perusahaan melunasi kemampuan jangka pendeknya. Berikut tabel-tabel yang menunjukkan pertumbuhan rasio likuiditas diukur dengan menggunakan lima indikator pada PT Bank Danamon Indonesia, Tbk, yaitu:

1. Quick Ratio (QR): Rasio ini menunjukkan kemampuan bank dalam melunasi kewajibannya dengan alat-alat yang dimiliki oleh bank.

2. Investing Policy Ratio (IPR): Rasio ini digunakan untuk mengukur kemampuan bank dalam melunasi kewajiban kepada para nasabah yang telah menanamkan dananya dengan mencairkan surat-surat berharga yang dimiliki bank. 
3. Loan to Deposit Ratio (LDR): Rasio ini digunakan untuk mengukur komposisi jumlah kredit dibandingkan dengan jumlah dana masyarakat dan modal sendiri yang digunakan. Bank Indonesia menetapkan bahwa rasio ini secara ideal berada di bawah $110 \%$. Pelampauan LDR lebih dari itu menyebabkan penilaian tingkat kesehatan bank akan berkurang.

4. Loan to Assets Ratio (LAR): Rasio ini untuk mengukur kemampuan bank dalam memenuhi permintaan para debitor dengan aset bank yang tersedia. Semakin tinggi tingkat rasio maka semakin rendah tingkat likuiditasnya.

5. Cash Ratio (CR): Rasio ini untuk mengetahui kemampuan bank dalam membayar kewajibannya yang sudah jatuh tempo dengan cash asset yang dimilikinya. Semakin tinggi rasio ini semakin tinggi tingkat likuiditasnya.

Tabel 3.1.

Perkembangan Rasio Likuiditas PT Bank Danamon Indonesia, Tbk. 2010-2012

\begin{tabular}{|c|r|r|r|}
\hline Keterangan & $\mathbf{2 0 1 0}(\mathbf{\%})$ & $\mathbf{2 0 1 1}(\mathbf{\%})$ & $\mathbf{2 0 1 2}(\boldsymbol{\%})$ \\
\hline Likuiditas & 18 & 16,91 & 21,62 \\
\hline a. QR & 22 & 21,70 & 13,63 \\
\hline b. IPR & 81,14 & 82 & 87,16 \\
\hline c. LDR & 59,11 & 59,20 & 61,98 \\
\hline d. LAR & 18,62 & 17,50 & 22,28 \\
\hline e. CR & & & \\
\hline
\end{tabular}

Sumber: Data Diolah

Dari data-data di atas bahwa likuiditas pada Bank Danamon pada tahun 2010-2012 meningkat. Hal ini dapat dilihat dari LDR yang terus meningkat tetapi masih berada di bawah batas maksimum $110 \%$ yang ditetapkan Bank Indonesia. Hal ini menadakan bahwa likuiditas Bank Danamon sehat. Jika dilihat dari IPR, angka yang dihasilkan dari tahun ke tahun mengalami penurunan. Hipotesis pertama dapat diterima, yaitu perhitungan rasio likuiditas Bank Danamon mengalami peningkatan dari tahun 2009-2012.

\subsubsection{Rasio Solvabilitas pada PT Bank Danamon Indonesia, Tbk \\ Rasio solvabilitas digunakan untuk} mengukur kemampuan perusahaan dalam membayar seluruh kewajiban.
Berikut yang menunjukkan pertumbuhan rasio solvabilitas dengan dua indikator:

1. Primary Ratio (PR): Digunakan untuk mengukur kemampuan permodalan pada suatu bank untuk menutup penurunan aktivanya akibat berbagai kerugian yang tidak dihindarkan.

2. Capital Adequacy Ratio (CAR): Rasio yang digunakan untuk mengukur kemampuan permodalan yang ada guna menutup kemungkinan kerugian di dalam perkreditan dan perdagangan suratsurat berharga (efek). Semakin besar rasio menandakan bank tersebut semakin solvable karena modal bank mampu menutupi kerugian atas kredit atau surat berharga. 
Tabel 3.2.

Perkembangan Rasio Solvabilitas PT Bank Danamon Indonesia, Tbk. 2010-2012

\begin{tabular}{|c|r|r|r|}
\hline Keterangan & $\mathbf{2 0 1 0}(\boldsymbol{\%})$ & $\mathbf{2 0 1 1}(\boldsymbol{\%})$ & $\mathbf{2 0 1 2}(\boldsymbol{\%})$ \\
\hline Solvabilitas & & & 7,61 \\
\hline a. PR & 7,62 & 8,95 & 11,25 \\
\hline b. CAR & 12,51 & 14,44 & \\
\hline
\end{tabular}

Sumber: Data Diolah

Tingkat solvabilitas Bank Danamon dari tahun 2010-2012 berfluktuasi. Hipotesis yang ketiga dapat diterima, yaitu perhitungan rasio solvabilitas Bank Danamon mengalami fluktuasi dari tahun 2010-2012.

\subsubsection{Rasio Profitabilitas pada PT Bank Danamon Indonesia, Tbk}

Rasio profitabilitas untuk mengukur kemampuan bank dalam menghasilkan laba selama periode tertentu dan untuk mengukur tingkat efektivitas manajemen dalam menjalankan operasional perusahaan. Berikut yang menunjukkan pertumbuhan rasio profitabilitas dengan empat indikator:
1. Gross Profit Margin (GPM): Untuk mengukur kemampuan bank dalam menghasilkan laba dari operasi usahanya yang murni.

2. Net Profit Margin (NPM): Untuk mengukur kemampuan bank dalam menghasilkan net income ditinjau dari sudut operating incomenya.

3. Return on Equity (ROE): Untuk mengukur kemampuan bank dalam menghasilkan laba ditinjau dari sudut ekuitas.

4. Return on Total Asset (ROA): Untuk mengukur kemampuan manajemen bank dalam mengelola aktiva yang dikuasainya untuk menghasilkan income.

Tabel 3.3.

Perkembangan Rasio Profitabilitas PT Bank Danamon Indonesia, Tbk.

2010-2012

\begin{tabular}{|c|r|r|r|}
\hline Keterangan & $\mathbf{2 0 1 0}(\mathbf{\%})$ & $\mathbf{2 0 1 1}(\mathbf{\%})$ & $\mathbf{2 0 1 2}(\mathbf{\%})$ \\
\hline Profitabilitas & & & 98,16 \\
\hline a. GPM & 74,36 & 74,82 & 33,69 \\
\hline b. NPM & 20,09 & 18,76 & 51,45 \\
\hline c. ROE & 32,69 & 31,53 & 3,92 \\
\hline d. ROA & 2,49 & 2,82 & \\
\hline
\end{tabular}

Sumber: Data Diolah

Dilihat dari data di atas menunjukkan bahwa tingkat profitabilitas Bank Danamon meningkat dari tahun ke tahun terutama tahun 2012. Hal ini disebabkan GPM dan ROA yang dihasilkan setiap tahunnya selalu mengalami peningkatan. Jika lihat NPM dan ROE maka profitabilitas mengalami penurunan pada tahun 2011, tetapi pada tahun 2012 mengalami peningkatan. Maka, hipotesis yang pertama dapat diterima, yaitu perhitungan rasio profitabilitas Bank Danamon mengalami peningkatan dari tahun 2010-2012. 


\subsection{Kebijakan Pembiayaan}

$\begin{array}{lr}\text { Kebijakan Bank } & \text { Danamon } \\ \text { mengenai pembiayaan, } & \text { yaitu } \\ \text { pembiayaan investasi, modal } & \text { kerja, } \\ \text { kopkar, danamon syariah, } & \text { dan } \\ \text { pembiayaan BPR Syariah untuk }\end{array}$ pembiayaan investasi berupa gadai emas di mana target dari produk pembiayaan masyarakat menengah ke bawah, seperti pedagang kisaran pendapatan sebesar tiga sampai lima juta rupiah per bulan. Pembiayaan modal kerja diperuntukkan khusus untuk UMKM. Pembiayaan kopkar Danamon Syariah dengan skema mudharabah (bagi hasil) kepada koperasi karyawan yang selanjutnya akan disalurkan kepada anggota koperasi karyawan, pembiayaan BPR Syariah untuk modal kerja.

Prosedur pembiayaan yang diterapkan Bank Danamon, yaitu 1) Persiapan pembiayaan, 2) Analisis pembiayaan, dan 3) Pembinaan Debitur. Persiapan pembiayaan terdapat bentuk laporan akuntansi, analisis pembiayaan yang dilakukan oleh Accounting Officer, dan pembinaan debitur yang di dalamnya terdapat instruksi persyaratan pembiayaan.

\subsection{Pengaruh Rasio Likuiditas, Solvabilitas, dan Profitabilitas dalam Mendukung Pembiayaan pada PT Bank Danamon Indonesia, Tbk.}

bahwa:

Berdasarkan hasil pengujian

1. Pembiayaan pada Bank Danamon pada tahun 2011 mengalami kenaikan sebesar Rp777.962. Hal ini disebabkan adanya kenaikan pada tingkat solvabilitas di mana primary ratio $(\mathrm{PR})$ mengalami kenaikan sebesar 1,3\% dan Capital Adequacy Ratio (CAR) mengalami kenaikan sebesar $1,93 \%$.

2. Pada tahun 2012 pembiayaan pada Bank Danamon mengalami kenaikan sebesar Rp4.008.387. Peningkatan pembiayaan ini terjadi karena kondisi Bank Danamon dalam keadaan liquid. Hal ini terbukti dari QR yang mengalami kenaikan sebesar 4,71\%, LAR sebesar $2,78 \%$, CR sebesar 4,78\%, dan LDR sebesar 5,16\%.

\section{KESIMPULAN}

1. Likuiditas pada Bank Danamon pada tahun 2010-2012 meningkat dan masih berada di bawah $110 \%$ Kemudian, tingkat solvabilitas Bank Danamon dari tahun 20102012 berfluktuasi. Sedangkan tingkat profitabilitas Bank Danamon meningkat dari tahun ke tahun terutama tahun 2012.

2. Pembiayaan modal kerja diperuntukkan khusus untuk UMKM. Pembiayaan kopkar Danamon Syariah dengan skema mudharabah (bagi hasil) kepada koperasi karyawan yang selanjutnya akan disalurkan kepada anggota koperasi karyawan, pembiayaan BPR Syariah untuk modal kerja. Prosedur pembiayaan yang diterapkan Bank Danamon, yaitu 1) Persiapan pembiayaan, 2) Analisis pembiayaan, dan 3) Pembinaan Debitur.

3. Pembiayaan pada Bank Danamon pada tahun 2011 mengalami kenaikan sebesar Rp777.962. Dan, Pada tahun 2012 pembiayaan pada Bank Danamon mengalami kenaikan sebesar Rp4.008.387. Peningkatan pembiayaan ini terjadi karena kondisi Bank Danamon dalam keadaan liquid.

\section{DAFTAR PUSTAKA}

Bambang Riyanto. 2008. Dasar-Dasar Pembelajaran Perusahaan. Yogyakarta: BPFE. 
Irham Fahmi. 2012. Analisis Laporan Keuangan. Bandung: Alfabeta.

Kieso D.E., J.J. Wegyant, and T.D. Warfield. 2009. Akuntansi Menengah. Jakarta: Erlangga.

Undang-Undang Nomor 10 Tahun 1998 tentang Perubahan atas UndangUndang Nomor 7 Tahun 1998 tentang Perbankan.

Veithzal Rivai. 2008. Islamic Financial Management. Jakarta: Raja Grafindo Persada. 